\title{
Non-traditional Southern Journalistic Civil Rights Advocacy In the U.S., 1950s-1960s
}

\section{Clarence W. Thomas*}

School of Mass Communications, Virginia Commonwealth University, USA

Many communications researchers and journalists who covered the civil rights movement have reported that most southern white-owned newspapers routinely portrayed blacks in a demeaning light during the early to mid-twentieth century. The southern white press was described as having ignored all but the most sensational and negative news from the black community [1]. Broadcaster Joseph Brechner argued that white press coverage of blacks constituted a "boycott or censorship of positive, favorable news" [2]. Researcher Lauren Kessler contended that when the white press did include news of blacks, it portrayed them as "clowns or criminals" [3].

Such practices were carried over to the early 1950s and the initial phases of the modern civil rights movement as the southern white press either ignored, downplayed, or reflected a negative perspective on desegregation efforts [4]. In addition, researcher Carol Martindale argued that the little attention paid to blacks reinforced negative racial stereotypes. Martindale maintained that blacks were consistently portrayed as criminals, and news about crimes committed by blacks was often given more coverage than crimes committed by whites. She asserted that among southern white newspapers it was a long-standing practice to run all accusations of sex crimes committed by blacks on page one of the paper even if the paper had to report stories from other cities [5]

Several white reporters who covered the movement forlarge southern and northern white newspapers also suggested that the southern white press presented negative coverage of blacks and the movement. Former Jackson State Times reporter Charles Dunagan revealed "A lot of us realized, deep down, that blacks were being mistreated" by the white press [6]. In addition, Alabama Times publisher Buford Boone contended that some southern white publishers downplayed news of blacks and the movement because to do otherwise would have been bad for business. In essence, according to Boone, "They [southern editors and publishers] let their obligation to their profession (objectivity, etc.) play second fiddle to their chamber of commerce membership [7]."

Despite the inadequate and slanted coverage of blacks and the movement by the southern white press, several courageous southern white journalists, in addition to the traditional and substantial coverage and advocacy provided by the black press, dared to advocate equality and civil rights for black Americans.

Harry Golden, editor of the Carolina Israelite and one of the most well-known and influential journalistic civil rights advocates, was joined by other white journalists in the fight for black civil rights. They include: Harry Ashmore, the executive editor of the Arkansas Gazette; Ralph McGill, the editor and publisher of the Atlanta Constitution; Percy Dale East, the owner/publisher/ editor of the Petal Paper; and William Hodding Carter, Jr., the owner/publisher/editor of the Greenville Delta Democrat-Times.

The work of the aforementioned journalists served to complement and facilitate the work and accomplishments of civil rights leaders, organizations, and workers. Despite the risk of economic and violent repercussions, these journalistic civil rights advocates actively sought and encouraged right over wrong during a time when speaking out against racism was unpopular. In the process, discussion of the race issue was kept before the white audiences, blacks were provided with encouragement, and racial understanding and acceptance were aided.

\section{References}

1. Aldo Morris (1984) The Origins of the Civil Rights Movement: Black Communities Organizing for a Change. Macmillan, New York 13; Henry Lewis Suggs (1983) The Black Press in the South, 1865-1979: Greenwood, 28: 142.

2. Joseph Brechner (1967) "Were Broadcasters Color Blind," Race and the News Media eds. Paul Fisher and Ralph Lowenstein Praege, New York 98-99.

3. Lauren Kessler (1984) The Dissident Press. Sage, Beverly Hills 24.

4. Dateline: The Press and Civil Rights Produced by Sue Ducat and Ricki Green, PBS, WUFT TV, Gainesville, FL 3 May 1989

5. Carolyn Martindale (1986) The White Press and Black America Greenwood, New York 56; Kessler 23

6. Charles Dunagan, interview, Dateline: The Press and Civil Rights. PBS. WUFT TV, Gainesville, FL 3 May 1989.

7. Buford Boone (1967) "Southern Newsmen and Local Pressure," Race and the News Media eds. Paul Fisher and Ralph Lowenstein. Praeger, New York 50.
*Corresponding author: Clarence W. Thomas, School of Mass Communications, Virginia Commonwealth University, USA, Tel: (804) 827-3772; E-mail: cwthomas@vcu.edu

Received May 04, 2012; Accepted May 14, 2012; Published May 21, 2012

Citation: Thomas CW (2012) Non-traditional Southern Journalistic Civil Rights Advocacy In the U.S., 1950s-1960s. J Mass Commun Journalism 2e119. doi:10.4172/2165$7912.1000 \mathrm{e} 119$

Copyright: ( 2012 Thomas CW. This is an open-access article distributed under the terms of the Creative Commons Attribution License, which permits unrestricted use, distribution, and reproduction in any medium, provided the original author and source are credited. 